\title{
REVIEW \\ Yaakov Y. Teppler \\ Birkat HaMinim: Jews and Christians in Conflict in the Ancient World
}

Trans. Susan Weingarten (Tübingen: Mohr Siebeck, 2007), 413 pp.

Reviewed by Ruth Langer, Boston College

Since the patristic period, the birkat haminim has attracted Christian attention. This twelfth benediction of the central, thrice-daily Jewish weekday prayer of eighteen benedictions (actually, for most of its history, nineteen), calls for the downfall of various categories of humans who harm the Jewish community. Instituted at Yavneh in the late first century according to talmudic tradition, it was understood by Jerome and Ephiphanius and perhaps even by Justin to curse Christians. The earliest preserved liturgical texts, from the end of the first Christian millennium (though not from Christian lands), would seem to confirm this, naming Christians explicitly. But was this the original intent and/or language of the prayer?

While many scholars have written on the birkat haminim and the question of the identity of the minim in general, Teppler's is only the second book-length treatment of the subject. ${ }^{1}$ The methodological challenges confronting such a study are overwhelming. From the perspective of understanding early Christian-Jewish relations and the parting(s) of the ways, it is obviously critical to determine whether the rabbis of the Land of Israel were so concerned about Christians in the late first century as to give them the attention of a thrice-daily liturgical curse. However, were the original minim Christians? Early rabbinic texts give very little concrete information by which to identify the minim, and the term aggregated new meanings over time. To what extent can the liturgical texts of a millennium later be retrojected to the first century? How much of their language and their malediction of several additional categories of people (especially apostates and the kingdom of arrogance) sheds light on the original situation of the blessing? How do we understand traditions, like the story of the institution of this prayer, that appear only in the Babylonian Talmud and not in earlier rabbinic texts or in texts from the Land of Israel? How quickly did this prayer become widely recited?

Teppler wades into this methodological morass. He devotes the second half of the book exclusively to determining who were the original minim. His exhaustive study of the minutiae of the available evidence results in a conclusion that the original minim, the objects of the prayer, were Christians, both Jewish and gentile. The first half focuses more specifically on the prayer itself. Rabbinic evidence shows that the original language of the prayer mentioned minim and closed with the eulogy, "makhnia' zedim" (who brings low the haughty). Although the term "notzerim" (Christians, Nazarenes) is well documented in the earliest surviving liturgical texts, Teppler argues that there is no evidence for Jewish use of the term in the first and second centuries, and no evidence for it in the prayer until the fourth century. Teppler also argues that "apostates," the term with which the vast majority of uncensored texts open this prayer, is an early medieval addition, probably of Babylonian provenance and in response to shifting meanings of the already embedded terms. Once "minim" comes to mean "Karaites," he claims,

\footnotetext{
${ }^{1}$ After R. Travers Herford, Christianity in Talmud and Midrash (London: Williams \& Norgate, 1903; rpt. New York:
} Ktav, n.d.). 
other terms become necessary, including "notzerim." Unfortunately, though, his argument for this relies on very little evidence and much assumption. That some rabbis call Karaites "minim" does not mean that all "minim" were Karaites. He also ignores entirely the third line of the later medieval blessing (addressing Israel's enemies). In the context of his detailed discussions, this reads like an oversight. Were his data better (see below), he could have justified his choice. He similarly never connects Saadia Gaon's text with the rich geniza evidence for its actual use.

Teppler queries whether the prayer for the downfall of the "kingdom of arrogance" is original to Yavneh. As it is unlikely that Rome would have tolerated such a prayer, especially in the period between and after the Jewish revolts, Teppler suggests two possibilities: either this phrase was later instituted against Rome by Babylonian Jews (and hence it was not original to Yavneh); or its original intent was not Rome at all, but the Christian understanding that in the period between the Resurrection and the Second Coming, the church represents the "kingdom of heaven" on earth. For the rabbis, this translated into the "kingdom of arrogance."

This last is an example of the major flaw of this massive book. The "kingdom of heaven" was indeed an important concept in the early church, but what did it mean? Teppler does not acknowledge the wide-ranging discussion among New Testament scholars about whether this meant something manifest in the contemporary church or something only anticipated eschatologically. In any case, how would the Romans know that the term "kingdom of arrogance" did not apply to them? Teppler's preferred theory, that in Babylonia, where there was no fear of retribution, Jews applied this term to Rome, is no less problematic. What would motivate such an addition to the prayer? And how did they make explicit to the Babylonian authorities that the prayer's object was Babylonia's own enemy! Here, and throughout his book, Teppler's claims are based on insufficiently grounded suppositions that subsequently become "fact" and the basis for further suppositions. This includes, especially, his assertion that the minim of the Yavneh period were exclusively Christians.

Teppler's use of rabbinic sources, including his consultation of manuscript variants, is mostly sound (provided that one accepts his frequently dating traditions according to their attributions) and, with the exception of his presumption, based on some older scholarship never well accepted and not consistently implemented even here, that the Tosefta is post-talmudic. His use of liturgical sources is more problematic. Unfortunately, his book probably went to press before my article with Uri Ehrlich appeared, publishing almost 200 manuscripts of the birkat haminim from the geniza and medieval European rites (among which Teppler fails to distinguish). ${ }^{2}$ Had he consulted with Ehrlich about the geniza materials, with Jonah Fraenkel about Ashkenazi liturgy, or with the late Ezra Fleischer about liturgical poetry, his discussion of the actual liturgical texts would have been grounded in state-of-the-art data. As it is, many of his details are partial or outright wrong, leading to mistaken suppositions and conclusions.

There is also much secondary material of relevance in English of which he seems unaware. To write on this topic and not engage explicitly the publications of Daniel Boyarin, Seth Schwartz, or Lee Levine, for instance, is a huge lacuna. In many cases, the secondary authors he does engage do not represent contemporary scholarship on the topic, but represent earlier stages methodologically in the project of Jewish Wissenschaft or outdated (or his own eclectic) understandings of Second Temple and early Christian history and literature. Consequently, he sees the Septuagint, Jubilees, and the Damascus Document as of no relevance as Jewish texts and fails to understand the contexts of the New Testament's books. He also views the Yavnean

\footnotetext{
2 "The Earliest Texts of the Birkat Haminim," Hebrew Union College Annual 76 (2006): 63-112.
} 
rabbis as having immediate success in promulgating throughout the world their innovative liturgical system, including the birkat haminim, an understanding many question.

Finally, the book badly needs editing. Teppler repeats himself and argues in circles. Confusingly, he regularly works backwards from more recent to older sources, something that is justified perhaps with regards to the first millennium text of the birkat haminim itself for lack of alternatives, but not beyond this. His tables presenting the geniza texts seem to have been corrupted, resulting in completely wrong information $(23,373)$. More seriously, the translation is frequently clumsy to the point of incomprehensibility, as it was not reworked into idiomatic English. The translator also does not know standard technical English vocabulary for the subject. The "eulogy" of the blessing appears here as its "close"; "resurrection" as "revival of the dead"; and "Sadducees" as "Zadokites," and once "Zadocean" (175). For a book this expensive, this is inexcusable.

Teppler is to be commended for undertaking an ambitious project, one central to understanding the early Jewish-Christian relationship. Anyone dealing with the birkat haminim or minim will need to evaluate his arguments carefully. But the last word on the topic has not yet been written and may never be written, simply because the available evidence rarely, in my opinion, supports the sort of firm conclusions Teppler proposes. 